\title{
METAFORA KATA MATA DALAM BAHASA MELAYU RIAU: ANALISIS SEMANTIK KOGNITIF
}

The Metaphor of The Word Mata in Malay Language of Riau:

Cognitive Semantic Analysis

\author{
Hermandra \\ Universitas Riau \\ Kampus Bina Widya KM. 12,5, Simpang Baru, Kota Pekanbaru, Indonesia \\ hermandra@lecturer.unri.ac.id
}

Naskah Diterima Tanggal 9 Februari 2020_-Direvisi Akhir Tanggal 5 Agustus 2021._Disetujui Tanggal 27 November 2021 doi: https://doi.org/10.26499/rnh.v10i2.2243

\begin{abstract}
Abstrak
Penelitian ini bertujuan untuk mengkaji metafora kata "mata" dalam bahasa Melayu Riau. Penelitian ini merupakan penelitian deskriptif kualitatif menggunakan analisis semantik kognitif. Data penelitian diambil dari tuturan masyarakat Melayu yang banyak menggunakan ungkapan metafora kata "mata". Teknik yang digunakan dalam mengumpulkan data adalah teknik wawancara yang dibantu dengan teknik pancing, sadap, dan simak libat cakap yang disertai dengan teknik rekam. Teknik analisis data berupa pengumpulan data, analisis data, dan penarikan simpulan. Hasil penelitian menunjukkan bahwa penggunaan kata mata dapat memunculkan berbagai ungkapan metafora dalam berbahasa masyarakat Melayu Riau. Secara secara praktis, penggunaan mata dapat ditemukan pada mata telanjang, mata pisau, mata nanas, mata kail, mata ikan, mata cincin, mata bisul, mata panda, kantong mata, mata kaki, mata kepala, dan mata ikan. Makna yang muncul dapat dipahami dan diinterpretasi secara logika melalui pengalaman hidup masyarakat Melayu Riau. Pengalaman sebagai penanda yang menjadi penghubung maksud dari ungkapan yang disampaikan masyarakat Melayu Riau saat berkomunikasi.
\end{abstract}

Kata-kata Kunci: metafora, bahasa Melayu, semantik kognitif

\begin{abstract}
This study aims to examine the metaphor of the word "eye" in Riau Malay. This research is a qualitative descriptive study using cognitive semantic analysis. The research data was taken from the speech of the Malay community who used the metaphorical expression of the word "eye". The technique used in collecting data is an interview technique assisted by fishing, tapping, and listening to conversational techniques accompanied by recording techniques. Data analysis techniques in the form of data collection, data analysis, and drawing conclusions. The results showed that the use of the word mata can bring up various metaphorical expressions in the language of the Riau Malay community. Practically, the use of the eye can be found in the eye of the basket, knife blade, pineapple eye, hook, fish eye, ring eye, boil eye, panda eye, eye bag, ankle, head eye, and fish eye. The meanings that emerge can be understood and interpreted logically through the life experiences of the Riau Malay community. Experience as a marker that connects the meaning of the expressions conveyed by the Riau Malay community when communicating.
\end{abstract}

Keywords: metaphor, Malay language, cognitive semantics

How to Cite: Hermandra. (2021). Metafora Kata Mata dalam Bahasa Melayu Riau: Analisis Semantik Kognitif. Ranah: Jurnal Kajian Bahasa. 10(2). 216-228. doi: https://doi.org/10.26499/rnh.v10i2.2243 


\section{PENDAHULUAN}

Dalam kehidupan masyarakat Melayu, penggunaan ungkapan dalam berbahasa merupakan hal yang biasa. Cara ini menjadi penciri dalam kehidupan masyarakat Melayu, khususnya masyarakat Melayu Riau. Masyarakat Riau berupaya menjaga lawan bicara untuk bisa merasa nyaman dalam berkomunikasi sehingga penggunaan ungkapan yang mengandung kias atau metafora menjadi cara yang dilakukan masyarakat Melayu di Riau. Selain itu, masyarakat Melayu Riau menggunakan ungkapan kias atau metafora sebagai ada dalam berbahasa dengan kata lain, mereka tidak selalu menyampaikan maksud secara langsung tetap tidak langsung, yaitu dengan penggunaan ungkapan-ungkapan metafora.

Ungkapan metafora disampaikan agar tidak menunjuk langsung pada objek yang dimaksud atau dituju. Penggunaan bahasa yang mengandung unsur metafora dilakukan sebagai suatu cara untuk menimbulkan efek tertentu sehingga penerima pesan lebih tertarik. Kata-kata tersebut dapat memperkaya dimensi bahasa dan makna (Kustina, 2019; Arianto, 2018). Semakin banyak ungkapan yang disampaikan masyarakat, khusus masyarakat Melayu maka memberikan potensi banyak ungkapan kias yang muncul dan terbentuk dari aktivitas dialog (Aidil \& Istiqomalia, 2021). Ungkapan kias ini menjadi penting dimaknai guna memperluas ruang kebahasaan, khususnya dalam aspek bertutur dan memberikan makna (Soli \& Sukirno, 2020).

Munculnya kias atau tuturan yang mengandung metafora pada dasarnya tidak terlepas dari etika dan kesantunan berbahasa yang menjadi jati diri masyarakat Melayu Riau. Kearifan berbahasa membuat ungkapan yang mengandung kias menjadi fenomena tersendiri dalam kehidupan masyarakat Riau (Warni \& Afria, 2020). Seperti pada ungkapan Ais adalah buah hati keluarga pak Anto. Ungkapan atau pernyataan ini bermakna anak kesayangan dari keluarga bapak Anto. Ungkapan ini tidak langsung menyebut Ais anak kesayangan, tetapi dikiaskan dengan buah hati. Keadaan ini menunjukkan suatu kearifan berbahasa yang dapat memberikan pandangan luas terhadap pemaknaan tuturan (Kustina, 2019).

Sesuai dengan penjelasan di atas, dapat diidentifikasi ada banyak bentuk ungkapan yang muncul dalam kehidupan masyarakat Melayu, baik dalam berpantun, bertutur dan sebagainya yang terkait dengan ungkapan kias seperti penggunaan kata buah hati, jantung hati, mata hati untuk menjelaskan objek tertentu. Berdasarkan hal tersebut penelitian ini mengangkat permasalahan mengenai pembentukan metafora dengan penggunaan kata mata yang bersanding pada kata lain dalam bahasa Melayu Riau, seperti mata hati pada ungkapan mereka sudah buta mata hati nuraninya. Ungkapan mata hati pada pernyataan tersebut dimaknai bahwa orang tersebut sudah tidak bisa menggunakan akal sehatnya dengan baik (Mislikhah, 2014).

Penelitian yang mengangkat masalah metafora telah banyak dilakukan oleh peneliti sebelumnya. Beberapa penelitian yang terkait dengan ranah metafora yaitu: Akastangga, 2020; Ardhianti, 2019; Firliandi, 2019; Kinanti \& Rachman, 2019; Kusmanto, 2019; Tama et al., 2019; Tengku \& Salehuddin, 2020; Tumuju \& Kamu, 2016. Namun, dari data penelitian terdahulu belum terdapat penelitian yang secara khusus membahas metafora kata mata dalam bahasa Melayu Riau dari perspektif semantik kognitif. Berdasarkan hal tersebut, penelitian ini bertujuan untuk mengkaji metafora kata dalam bahasa Melayu Riau menggunakan telaah semantik kognitif.

Mata merupakan salah satu alat indra manusia. Menurut Kamus Besar Bahasa Indonesia (KBBI), mata memiliki arti indra untuk melihat. Kata mata banyak digunakan untuk dalam metafora. Misalnya ungkapan metafora mata kepala, mata pisau, dan lain-lain. Oleh karena itu, tulisan ini membahas permasalahan tentang penggunaan metafora kata mata yang terdapat dalam bahasa Melayu Riau. Dengan adanya deskripsi tentang metafora kata mata ini, dapat diketahui apa saja ungkapan yang digunakan masyarakat Melayu Riau khusus tentang kata 
mata, sehingga ungkapan tersebut dapat dilestarikan sebagai warisan budaya di bidang bahasa dan dapat digunakan dalam kehidupan sehari-hari.

\section{LANDASAN TEORI}

Metafora sering digunakan dalam bahasa Melayu. Hal ini tidak terlepas dari penggunaan bahasa Melayu Riau yang dominan menggunakan ungkapan. Metafora merupakan ungkapan yang digunakan untuk memuji dan menyindir seseorang secara tidak langsung. Ungkapan ini memerlukan suatu tafsiran agar makna yang dimaksud dalam tuturan tersebut dapat dipahami. Pemaknaan tersebut pada hakikatnya tidak berarti makna yang sebenarnya tetapi sebuah makna yang muncul dan ditafsirkan dari proses pemahaman dan pengalaman. Semakin luas pemahaman, pengetahuan, dan pengalaman seseorang maka akan terbantu dalam memberikan makna pada ungkapan tersebut. Pada konteks ini suatu ungkapan memerlukan pemaknaan melalui pendekatan pemahaman, pengetahuan, dan pengalaman tertentu yang selanjutnya disebut dengan semantik kognitif.

Menurut Parera (2004) metafora adalah pergeseran makna dari dua hal yang dibandingkan dan terkait dengan pengalaman. Metafora selalu berhubungan dengan konteks dan pengalaman. Makna yang dihasilkan tidak dianalisis menggunakan makna leksikal dari setiap kata yang terlibat. Untuk menginterpretasi makna sebuah metafora dapat digunakan pengetahuan kultural yang didapatkan dari sebuah pengalaman. Dijelasakan bahwa metafora adalah bahasa nonliteral yang mengungkapkan perbandingan dua hal secara implisit (Wiradharma, 2016). Implisit berarti adanya makna yang terkandung namun tidak disebutkan secara terang-terangan. Artinya, di dalam metafora adanya dua atau beberapa kata yang hanya bisa dimaknai apabila dua kata atau lebih tersebut digabungkan.

Metafora merupakan pengalihan makna atas dasar kesamaan bentuk, fungsi, dan kegunaan (Erfiani \& Neno, 2021). Pengalihan makna tersebut merupakan wujud dari perbandingan dua hal secara implisit. Penjelasan metafora ini sejalan dengan dua pakar sebelumnya. Dikatakan bahwa metafora merupakan wujud dari perbandingan dua hal secara implisit. Dalam metafora ada keterlibatan dari sebuah persamaan baik itu dari segi bentuk, fungsi, dan kegunaan. Hal ini menandakan bahwa untuk menentukan makna sebuah metafora perlu pengamatan yang baik agar mendapatkan hasil yang sesuai dengan yang diharapkan.

Selain itu, metafora juga sebagai ungkapan bahasa yang digunakan dalam ungkapan bahasa lain yang berbentuk penggambaran (Tengku \& Salehuddin, 2020). Metafora mengungkapkan sesuatu dengan cara memberikan sebuah gambaran. Hal ini terjadi karena metafora tidak menyatakan sesuatu secara implisit. Metafora menggunakan bahasa kias agar setiap orang bisa menginterpretasi makna yang terdapat dalam sebuah metafora. Mengingat metafora ini memerlukan suatu pemakanaan, proses tersebut memerlukan pendekatan yang disebut semantik kognitif. Bidang semantik kognitif adalah bidang yang mengacu pada pengalaman (experientialist approach) yang mengambil pengalaman lampau dan alam sekeliling (Jalaluddin et al., 2012). Makna dilihat sebagai struktur konseptual yang lazim. Hal ini berarti dalam semantik kognitif hal yang menjadi perhatian dan titik tumpu adalah pengetahuan berdasarkan pengalaman. Makna yang dihasilkan dalam kajian semantik kognitif adalah makna yang didasari proses berpikir secara alamiah.

Dalam kontek kognitif berusaha mengeksplorasi interaksi alami manusia dihubungkan dengan lingkungan dan dunia (Wiradharma, 2016). Kognitif tidak hanya terbatas pada pengetahuan kebahasaan di dalam kamus. Semantik kognitif menjadi pintu masuk untuk pengetahuan lain yang lebih luas, yaitu pengetahuan kultural atas dasar pengalaman yang didapat. Prinsip analisis semantik kognitif berupa pembentukan konsep, struktur semantik, representasi makna, dan pembentukan makna (Dessiliona \& Tajudin, 2018). Artinya, untuk 
mengetahui makna sebuah metafora menggunakan analisis semantik kognitif harus mempelajari prinsip-prinsip yang telah ditetapkan.

\section{METODE PENELITIAN}

Penelitian ini merupakan penelitian deskriptif kualitatif. Penelitian kualitatif adalah cara untuk mendeskripsikan dan menganalisis fenomena, peristiwa, aktivitas sosial, sikap kepercayaan, persepsi, dan pemikiran orang secara individual maupun kelompok (Hermandra \& Zulhafizh, 2019; Jalaluddin et al., 2012). Dalam penelitian ini, metode yang digunakan adalah metode deskriptif kualitatif. Metode deskripsi merupakan analisis data dengan cara mendeskripsikan fakta-fakta yang ada, kemudian disusul dengan menguraikan data yang diperoleh dalam bentuk kata-kata (Sulistyaningsih et al., 2020). Dalam hal ini tidak dituangkan dalam bentuk bilangan atau angka.

Teknik pengumpulan data menggunakan teknik wawancara yang dibantu dengan teknik pancing, sadap, simak cakap, dan teknik rekam. Teknik sadap adalah teknik yang digunakan untuk menyadap pemakaian ungkapan (Mangangue, 2019) mata secara lisan dalam masyarakat Melayu. Kemudian, teknik simak cakap adalah teknik yang dilakukan dengan menyimak pembicaraan masyarakat tertentu. Teknik simak ini disertai dengan teknik rekam yaitu merekam pembicaraan masyarakat tentang ungkapan mata. Adapun teknik analisis data dilakukan setelah data terkumpul. Kemudian dilanjutkan dengan analisis konsepsi terhadap ungkapan tersebut sehingga dapat dipetakan secara objektif makan yang terkandung dalam ungkapan tersebut melalui bantuan skema imej. Setelah proses tersebut dilakukan dan dilalui, maka dilakukan penarikan simpulan.

Untuk menjaga keabsahan data dan analisis data, maka dilakukan triangulasi terhadap data-data tuturan masyarakat Melayu Riau. Adapun tindakan yang dilakukan, yaitu: melakukan survei terhadap informan yang benar-benar penduduk asli masyarakat Melayu Riau, menetap, bekerja, atau berusaha di Riau, minimal berusia 35 dan maksimal 60 tahun, aktif menggunakan bahasa Melayu dalam berkomunikasi, dan penutur sebagai sumber data harus sehat secara mental dan akal. Hal ini bertujuan guna mendapatkan data yang akurat dan faktual. Data-data yang terkumpul dan telah diklasifikasikan dimaknai dan diinterpretasi maksudnya dengan pendekatan semantik kognitif, baik dengan bantuan responden maupun peneliti.

\section{PEMBAHASAN}

Dalam penelitian ini hal yang menjadi pembahasan adalah konsep makna yang dihasilkan dari metafora kata "mata". Berikut data yang telah dikumpulkan.

Tabel 1.

\begin{tabular}{cc} 
& Metafora Kata "Mata" dan Makna \\
\hline No & Metafora \\
\hline 1 & Mata kaki \\
2 & Mata kepala \\
3 & Mata telanjang \\
4 & Mata pisau \\
5 & Mata nanas \\
6 & Mata kail \\
7 & Mata ikan \\
8 & Mata cincin \\
9 & Mata bisul \\
10 & Mata panda \\
11 & Kantong mata \\
12 & Mata duitan \\
\hline
\end{tabular}


Data $1 \rightarrow$ Mata Kaki

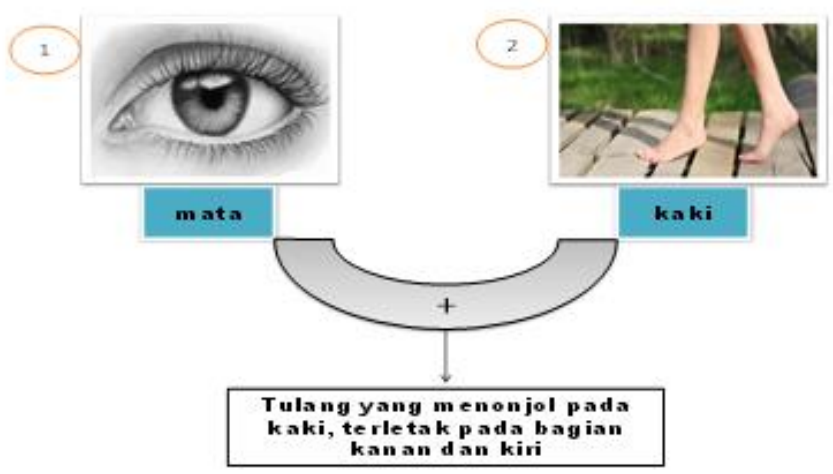

Sumber: https://www.worldofghibli.id/wp-content/uploads/2020/01/sketsa-gambar mata.jpg \& https://www.google.com/url?sa=i\&url=https $\% 3 \mathrm{~A} \% 2 \mathrm{~F} \% 2 \mathrm{Fwww}$.merdeka.com\%2Fsehat\%2Fberjalan-kaki-tanpa-alas-kakijuga-bisa-munculkan-bahaya-berikut-ini.jpg

Setiap makna yang dihasilkan tentu memiliki konsep. Hal ini akan menjadi acuan mengapa seseorang atau sekelompok orang memberikan makna terhadap sesuatu. Konsep makna dalam sebuah metafora dapat dipahami secara gramatikal. Artinya, peran konteks dan pengalaman sangat membantu untuk memahami sebuah metafora. Pada data 1, Gambar 1: "mata" jika diartikan secara leksikal bermakna alat indra yang digunakan untuk melihat. Gambar 2: "kaki" jika diartikan secara leksikal bermakna anggota badan yang menopang tubuh dan dipakai untuk berjalan.

Untuk mengetahui makna metafora "mata kaki" perlu memperhatikan keterkaitan ungkapan dengan pengetahuan kultural atau pengalaman manusia. "Mata kaki" merupakan tulang yang menonjol pada bagian bawah kaki yang berbentuk bulat. Mengapa disebut dengan mata kaki? Karena bentuknya yang bulat digambarkan seperti mata yang memiliki bentuk yang sama dan posisinya berada di kaki bagian bawah.

Data $2 \rightarrow$ Mata Kepala

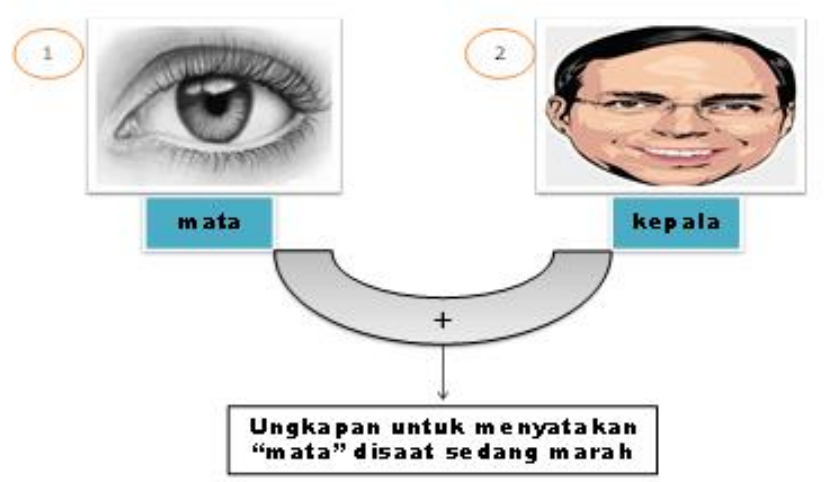

Sumber: https://www.worldofghibli.id/wp-content/uploads/2020/01/sketsa-gambar mata.jpg \& https://www.google.com/search?q=gambar+kepala

Setiap makna yang dihasilkan tentu memiliki konsep. Hal ini akan menjadi acuan mengapa seseorang atau sekelompok orang memberikan makna terhadap sesuatu. Konsep makna dalam sebuah metafora dapat dipahami secara gramatikal. Artinya, peran konteks dan pengalaman sangat membantu untuk memahami sebuah metafora. Pada data 2, Gambar 1: "mata" jika diartikan secara leksikal bermakna 'alat indra yang digunakan untuk melihat.' Gambar 2: "kepala" jika diartikan secara leksikal bermakna 'bagian tubuh yang berada di atas leher.' 
Untuk mengetahui makna metafora "mata kepala" perlu memperhatikan keterkaitan ungkapan dengan pengetahuan kultural atau pengalaman manusia. "Mata kaki" merupakan ungkapan untuk menyatakan alat indra yaitu mata, namun dalam keadaan sedang marah. Mengapa disebut dengan mata kepala? Jika dianalisis, kepala merupakan organ tubuh yang berada pada posisi paling atas dari seluruh anggota tubuh manusia. Ketika seseorang sedang marah, tanpa disadari bahwa ia sedang berada pada posisi puncak atau teratas dari ketidaksenangannya terhadap sesuatu. Posisi atau kedudukan itulah yang membuat orang Melayu untuk menyebut keadaan tersebut sebagai "mata kepala".

Data $3 \rightarrow$ Mata Telanjang

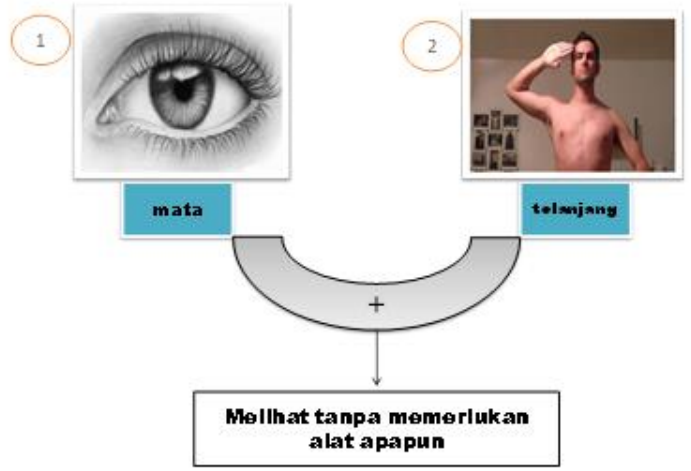

Sumber: https://www.worldofghibli.id/wp-content/uploads/2020/01/sketsa-gambar mata.jpg \& https://statik.tempo.co/data/2012/08/30/id_137486/137486_620.jpg

Setiap makna yang dihasilkan tentu memiliki konsep. Hal ini akan menjadi acuan mengapa seseorang atau sekelompok orang memberikan makna terhadap sesuatu. Konsep makna dalam sebuah metafora dapat dipahami secara gramatikal. Artinya, peran konteks dan pengalaman sangat membantu untuk memahami sebuah metafora. Pada data 3, Gambar 1: "mata" jika diartikan secara leksikal bermakna 'alat indra yang digunakan untuk melihat'. Gambar 2: "telanjang” jika diartikan secara leksikal bermakna 'tidak berpakaian'.

Untuk mengetahui makna metafora "mata telanjang" perlu memperhatikan keterkaitan ungkapan dengan pengetahuan kultural atau pengalaman manusia. "Mata telanjang" merupakan ungkapan untuk melihat sesuatu tanpa menggunakan bantuan alat selain mata. Tidak berpakaian merupakan makna dari kata "telanjang" yang diambil oleh orang Melayu untuk menyamakan persepsi dengan makna "mata telanjang". Hal ini dibuktikan dengan seseorang yang melihat tanpa memerlukan alat lain, misalnya teropong, kacamata, dan lain sebagainya. Artinya, ada persamaan yang dibuat oleh masyarakat Melayu untuk mengungkapkan sesuatu menggunakan bahasa yang perlu dipahami secara gramatikal.

Data $4 \rightarrow$ Mata Pisau

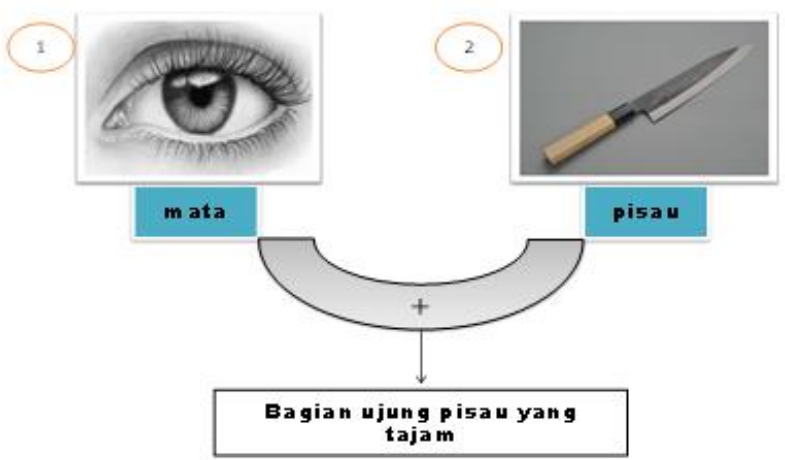

Sumber: https://www.worldofghibli.id/wp-content/uploads/2020/01/sketsa-gambar mata.jpg \& https://i.imgur.com/Ru9762S.jpg 
Setiap makna yang dihasilkan tentu memiliki konsep. Hal ini akan menjadi acuan mengapa seseorang atau sekelompok orang memberikan makna terhadap sesuatu. Konsep makna dalam sebuah metafora dapat dipahami secara gramatikal. Artinya, peran konteks dan pengalaman sangat membantu untuk memahami sebuah metafora. Pada data 4, Gambar 1: "mata" jika diartikan secara leksikal bermakna 'alat indra yang digunakan untuk melihat'. Gambar 2: "pisau" jika diartikan secara leksikal bermakna 'bilah besi tipis dan tajam yang bertangkai, sebagai alat pengiris dan sebagainya'.

Untuk mengetahui makna metafora "mata pisau" perlu memperhatikan keterkaitan ungkapan dengan pengetahuan kultural atau pengalaman manusia. "Mata pisau" merupakan ungkapan yang menyatakan 'bagian ujung pisau yang tajam'. Mengapa dikatakan mata pisau? Jika dianalisis, mata merupakan organ tubuh yang digunakan untuk melihat. Mata memiliki sisi ketajaman saat melihat sesuatu. Sebagai contoh, ketika kita melihat seseorang dengan tatapan yang serius, maka orang tersebut akan berkata "tajam sekali tatapanmu." Hal ini menandakan adanya persamaan yang dibuat oleh masyarakat Melayu untuk menyatakan bagian ujung pisau yang tajam yaitu dengan sebutan "mata pisau"

Data $5 \rightarrow$ Mata Nanas

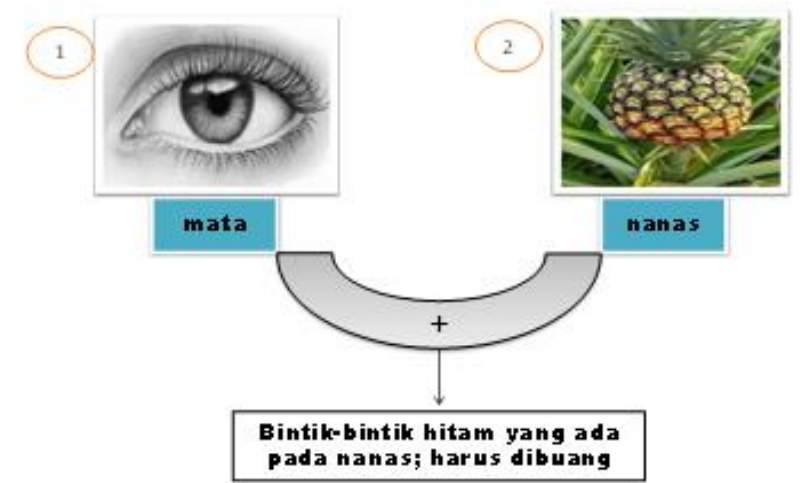

Sumber: https://www.worldofghibli.id/wp-content/uploads/2020/01/sketsa-gambar mata.jpg \& data:image/jpeg;

Setiap makna yang dihasilkan tentu memiliki konsep. Hal ini akan menjadi acuan mengapa seseorang atau sekelompok orang memberikan makna terhadap sesuatu. Konsep makna dalam sebuah metafora dapat dipahami secara gramatikal. Artinya, peran konteks dan pengalaman sangat membantu untuk memahami sebuah metafora. Pada data 5, Gambar 1: "mata" jika diartikan secara leksikal bermakna 'alat indra yang digunakan untuk melihat'. Gambar 2: "nanas" jika diartikan secara leksikal bermakna tanaman tropis dan subtropis, buahnya berbentuk bulat panjang, kira-kira sebesar kepala orang, kulit buahnya bersusun sisik, berbiji mata banyak, daunnya panjang, berserat, dan berduri pada kedua belah sisinya.

Untuk mengetahui makna metafora "mata nanas" perlu memperhatikan keterkaitan ungkapan dengan pengetahuan kultural atau pengalaman manusia. "Mata nanas" merupakan ungkapan yang menyatakan bintik-bintik hitam yang ada pada nanas. Mengapa dikatakan mata nanas? Jika dianalisis, mata merupakan organ tubuh yang memiliki bentuk bulat dengan lensa yang berwarna hitam (untuk orang Asia). Kemudian jika dilihat, bintik-bintik pada nanas yang berwarna hitam memiliki kemiripan dari segi bentuk dengan mata. Inilah yang membuat masyarakat Melayu memberikan ungkapan "mata nanas" untuk menyatakan bintik-bintik hitam yang ada pada nanas. 


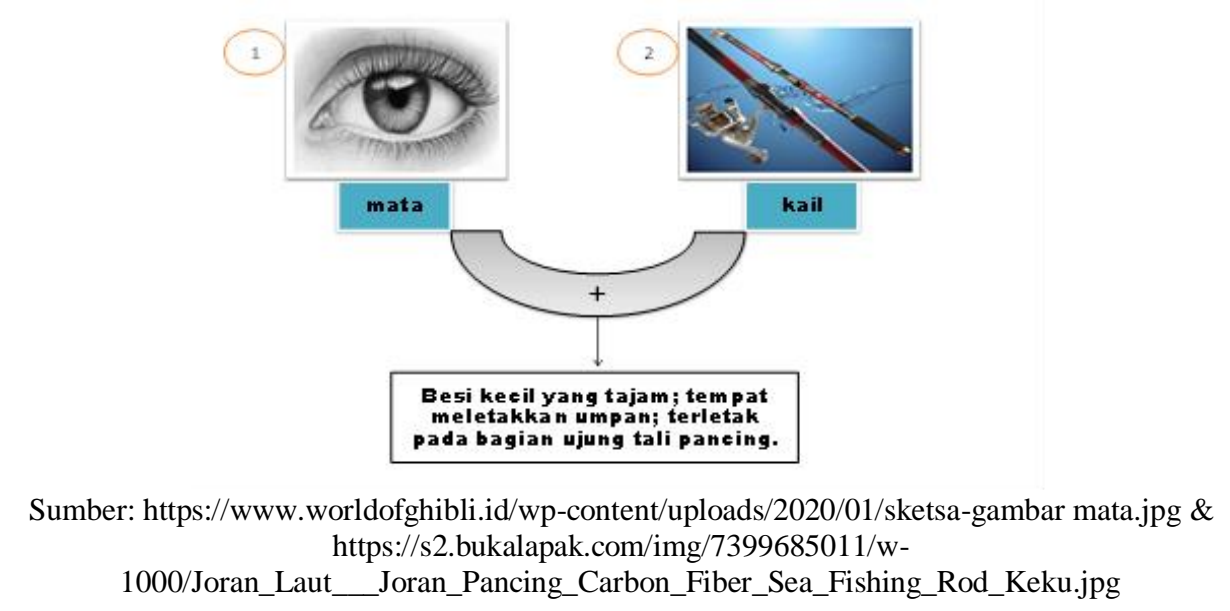

Setiap makna yang dihasilkan tentu memiliki konsep. Hal ini akan menjadi acuan mengapa seseorang atau sekelompok orang memberikan makna terhadap sesuatu. Konsep makna dalam sebuah metafora dapat dipahami secara gramatikal. Artinya, peran konteks dan pengalaman sangat membantu untuk memahami sebuah metafora. Pada data 6, Gambar 1: "mata" jika diartikan secara leksikal bermakna 'alat indra yang digunakan untuk melihat'. Gambar 2: "kail” jika diartikan secara leksikal bermakna sekerat kawat yang ujungnya berkait dan tajam, digunakan untuk menangkap ikan; pancing.

Untuk mengetahui makna metafora "mata kail" perlu memperhatikan keterkaitan ungkapan dengan pengetahuan kultural atau pengalaman manusia. "Mata kail" merupakan ungkapan yang menyatakan besi kecil tajam pada pancing, sebagai tempat meletakkan umpan, dan berada pada bagian ujung tali pancing. Mengapa dikatakan mata kail? Jika dianalisis, mata merupakan alat indera yang memiliki ketajaman melihat yang luar biasa. Kemudian jika dilihat, kawat besi kecil yang maksud juga harus tajam karena bertujuan untuk menangkap ikan. Inilah yang membuat masyarakat Melayu memberikan ungkapan "mata kail" untuk menyatakan besi kecil tajam pada pancing, sebagai tempat meletakkan umpan, dan berada pada bagian ujung tali pancing.

Data $7 \rightarrow$ Mata Ikan

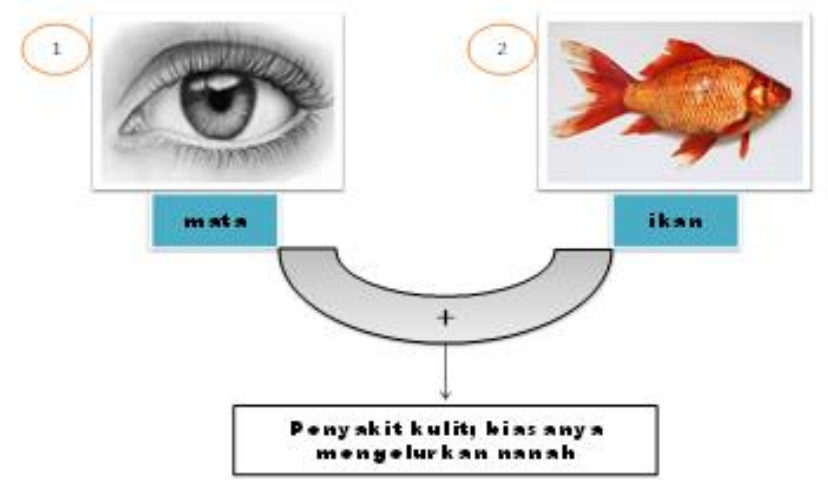

Sumber: https://www.worldofghibli.id/wp-content/uploads/2020/01/sketsa-gambar mata.jpg \& https://cdn.pixabay.com/photo/2014/11/19/15/05/goldfish-537832_340.jpg

Setiap makna yang dihasilkan tentu memiliki konsep. Hal ini akan menjadi acuan mengapa seseorang atau sekelompok orang memberikan makna terhadap sesuatu. Konsep makna dalam sebuah metafora dapat dipahami secara gramatikal. Artinya, peran konteks dan pengalaman sangat membantu untuk memahami sebuah metafora. Pada data 7, Gambar 1: 
"mata" jika diartikan secara leksikal bermakna 'alat indra yang digunakan untuk melihat'. Gambar 2: "ikan" jika diartikan secara leksikal bermakna binatang bertulang belakang yang hidup dalam air, berdarah dingin, umumnya bernapas dengan insang.

Untuk mengetahui makna metafora "mata ikan" perlu memperhatikan keterkaitan ungkapan dengan pengetahuan kultural atau pengalaman manusia. "Mata ikan" merupakan ungkapan yang menyatakan penyakit kulit yang memiliki bintik-bintik kecil berisi nanah. Mengapa dikatakan mata ikan? Jika kita pernah melihat mata ikan, maka akan tampak oleh kita bentuk mata ikan itu seperti apa. Mata ikan berbentuk bulat kecil, berwarna putih. Oleh masyarakat Melayu, bentuk mata ikan dijadikan persamaan untuk mengungkapkan beberapa penyakit yang memiliki bintik-bintik kecil yang berisi nanah. Penyakit kulit yang dimaksud, seperti jerawat, dll.

Data $8 \rightarrow$ Mata Cincin

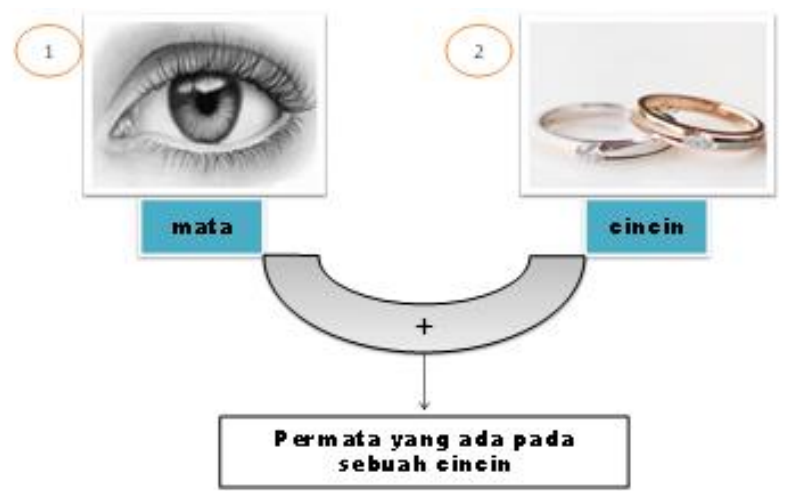

Sumber: https://www.worldofghibli.id/wp-content/uploads/2020/01/sketsa-gambar mata.jpg \& https://www.cincinkawinstore.com/wp-content/uploads/2016/09/image-19.jpeg

Setiap makna yang dihasilkan tentu memiliki konsep. Hal ini akan menjadi acuan mengapa seseorang atau sekelompok orang memberikan makna terhadap sesuatu. Konsep makna dalam sebuah metafora dapat dipahami secara gramatikal. Artinya, peran konteks dan pengalaman sangat membantu untuk memahami sebuah metafora. Pada data 8, Gambar 1: "mata" jika diartikan secara leksikal bermakna 'alat indra yang digunakan untuk melihat'. Gambar 2: "cincin" jika diartikan secara leksikal bermakna perhiasan berupa lingkaran kecil yang dipakai di jari, ada yang berpermata, ada yang tidak.

Untuk mengetahui makna metafora "mata cincin" perlu memperhatikan keterkaitan ungkapan dengan pengetahuan kultural atau pengalaman manusia. "Mata cincin" merupakan ungkapan yang menyatakan permata yang ada pada sebuah cincin. Mengapa dikatakan mata cincin? Permata yang ada pada cincin disamakan dengan mata secara bentuk. Mata memiliki bentuk yang bulat, begitu juga dengan permata. Selain itu, mata dianggap sebagai organ tubuh yang paling indah jika dilihat meskipun mata memiliki bentuk yang kecil. Hal ini menjadi ungkapan yang dibuat oleh masyarakat Melayu untuk mengungkapkan pertama yang indah pada sebuah cincin. 
Setiap makna yang dihasilkan tentu memiliki konsep. Hal ini akan menjadi acuan mengapa seseorang atau sekelompok orang memberikan makna terhadap sesuatu. Konsep makna dalam sebuah metafora dapat dipahami secara gramatikal. Artinya, peran konteks dan pengalaman sangat membantu untuk memahami sebuah metafora. Pada data 9, Gambar 1: "mata" jika diartikan secara leksikal bermakna 'alat indra yang digunakan untuk melihat'. Gambar 2: "bisul" jika diartikan secara leksikal bermakna bintil yang membengkak pada kulit berisi nanah dan bermata; barah.

Untuk mengetahui makna metafora "mata bisul" perlu memperhatikan keterkaitan ungkapan dengan pengetahuan kultural atau pengalaman manusia. "Mata bisul" merupakan ungkapan yang menyatakan bagian ujung bisul yang bernanah. Mengapa dikatakan mata bisul? Jika dianalisis dari segi bentuk, mata memiliki bentuk yang bulat. Begitu juga ujung bisul yang berbentuk bulat di dalamnya terdapat nanah. Kedua hal tersebut secara sekilas terdapat kesamaan dalam bentuk. Hal ini yang menyebabkan orang Melayu sering mengatakan bintilan pada bisul yang bernanah dengan ungkapan mata bisul.

Data $10 \rightarrow$ Mata Panda

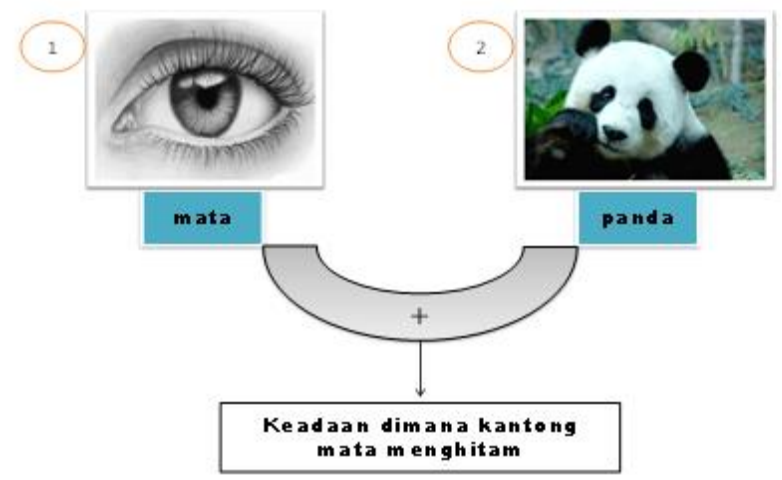

Sumber: https://www.worldofghibli.id/wp-content/uploads/2020/01/sketsa-gambar mata.jpg \& https://2.bp.blogspot.com/VH1bPB0tvs0/VV1Uvt3mfhI/AAAAAAAAL48/UnyhZSbOyMM/s1600/gambar\%2Bpanda\%2B\%252819\%2529.jpg

Setiap makna yang dihasilkan tentu memiliki konsep. Hal ini akan menjadi acuan mengapa seseorang atau sekelompok orang memberikan makna terhadap sesuatu. Konsep makna dalam sebuah metafora dapat dipahami secara gramatikal. Artinya, peran konteks dan pengalaman sangat membantu untuk memahami sebuah metafora. Pada data 10, Gambar 1: "mata" jika diartikan secara leksikal bermakna 'alat indra yang digunakan untuk melihat'. Gambar 2: "panda" jika diartikan secara leksikal bermakna binatang mamalia yang biasanya diklasifikasikan ke dalam keluarga beruang. 
Untuk mengetahui makna metafora "mata panda" perlu memperhatikan keterkaitan ungkapan dengan pengetahuan kultural atau pengalaman manusia. "Mata panda" merupakan ungkapan yang menyatakan kantong mata yang berwarna gelap atau menghitam. Mengapa dikatakan mata panda? Orang Melayu sering menyamakan sesuatu untuk menyatakan sebuah konsep makna. Jika dilihat, pada mata panda memang terdapat lingkaran hitam. Namun hal itu tidak akan terjadi pada mata manusia. Akan tetapi, mata manusia bisa saja menghitam pada bagian kantong mata. Hal ini dapat terjadi karena terlalu sering tidur larut malam. Melihat fenomena mata menghitam yang terjadi pada mata manusia, maka orang Melayu menyamakan hal tersebut dengan mata panda.

Data $11 \rightarrow$ Kantong Mata

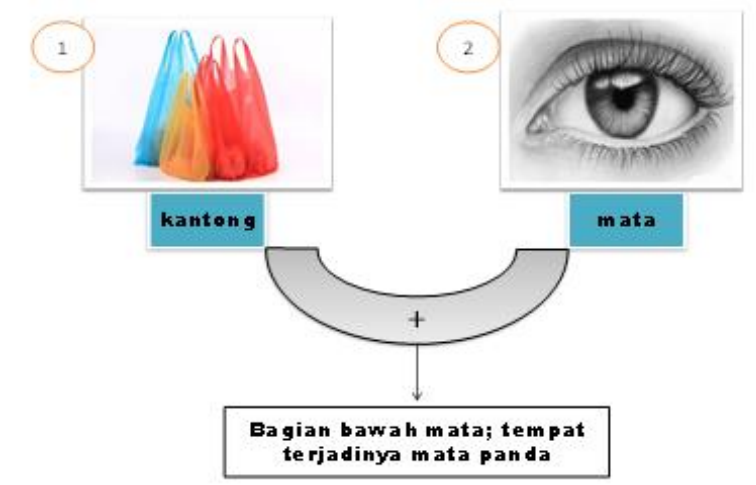

Sumber: https://statik.tempo.co/data/2018/12/11/id_803289/803289_720.jpg \& https://www.worldofghibli.id/wpcontent/uploads/2020/01/sketsa-gambar mata.jpg

Setiap makna yang dihasilkan tentu memiliki konsep. Hal ini akan menjadi acuan mengapa seseorang atau sekelompok orang memberikan makna terhadap sesuatu. Konsep makna dalam sebuah metafora dapat dipahami secara gramatikal. Artinya, peran konteks dan pengalaman sangat membantu untuk memahami sebuah metafora. Pada data 11, Gambar 1: "kantong" jika diartikan secara leksikal bermakna tempat membawa sesuatu yang terbuat dari kain, plastik, dan sebagainya. Gambar 2: "mata" jika diartikan secara leksikal bermakna alat indra yang digunakan untuk melihat.

Untuk mengetahui makna metafora "kantong mata" perlu memperhatikan keterkaitan ungkapan dengan pengetahuan kultural atau pengalaman manusia. "Kantong mata" merupakan ungkapan yang menyatakan bagian bawah mata, tempat terjadinya mata panda. Mengapa dikatakan kantong mata? Fungsi kantong salah satunya sebagai wadah menaruh barang. Pada kondisi tertentu bagian mata bisa menghasilkan kantong mata. Hal ini dapat terjadi karena pengaruh usia, terlalu sedikit istirahat, dan lain sebagainya. Kantong mata memiliki bentuk yang cekung pada bawah mata. Sehingga tampak seperti adanya ruang pada bawah mata. Ruang tersebut seolah-olah memiliki volume. Itulah yang menyebabkan masyarakat Melayu menyebut bagian bawah mata dengan ungkapan kantong mata. 


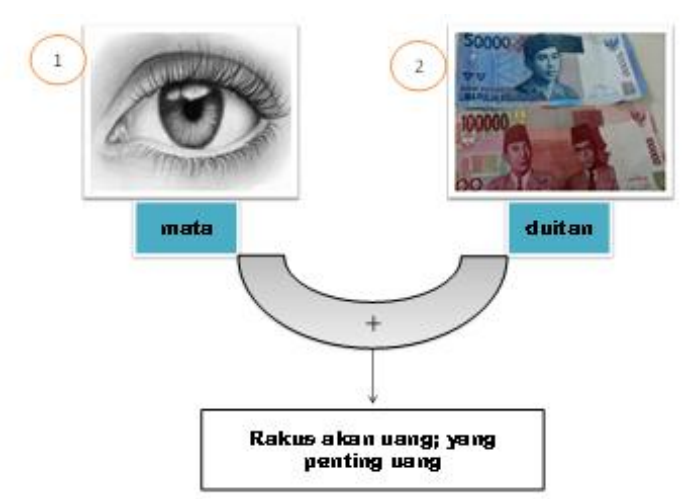

Sumber: https://www.worldofghibli.id/wp-content/uploads/2020/01/sketsa-gambar mata.jpg \& https://asseta.grid.id//crop/0x0:0x0/700x465/photo/bobofoto/original/18954_gambar-uang-pada-uang-rupiah.jpg

Setiap makna yang dihasilkan tentu memiliki konsep. Hal ini akan menjadi acuan mengapa seseorang atau sekelompok orang memberikan makna terhadap sesuatu. Konsep makna dalam sebuah metafora dapat dipahami secara gramatikal. Artinya, peran konteks dan pengalaman sangat membantu untuk memahami sebuah metafora. Pada data 12, Gambar 1: "mata" jika diartikan secara leksikal bermakna 'alat indra yang digunakan untuk melihat'. Gambar 2: "duit" jika diartikan secara leksikal bermakna uang, alat pembayaran.

Untuk mengetahui makna metafora "mata duitan" perlu memperhatikan keterkaitan ungkapan dengan pengetahuan kultural atau pengalaman manusia. "Mata duitan" merupakan ungkapan yang menyatakan orang yang rakus akan uang. Mata merupakan alat indera yang memiliki kemampuan memandang sesuatu paling jauh. Artinya, mata memiliki kemampuan luar biasa untuk menjangkau sesuatu. Mata duitan diibaratkan sebagai orang rakus yang ingin melakukan apapun demi uang. Ia bisa melakukan apapun untuk menjangkau sesuatu yang berhubungan dengan uang. Secara tidak langsung dia memiliki kekuatan untuk melakukan hal tersebut. Itulah yang menyebabkan orang Melayu mengatakan mata duitan untuk orang rakus yang melakukan apapun demi uang.

\section{PENUTUP}

Berdasarkan permasalahan yang telah dikaji dalam penelitian ini, disimpulkan bahwa penggunaan kata mata dapat memunculkan berbagai ungkapan metafora dalam berbahasa masyarakat Melayu Riau. Secara secara praktis, penggunaan mata dapat ditemukan pada mata telanjang, mata pisau, mata nanas, mata kail, mata ikan, mata cincin, mata bisul, mata panda, kantong mata, mata kaki, mata kepala, dan mata ikan. Makna yang muncul dapat dipahami dan interpretasi secara logika melalui pengalaman hidup masyarakat Melayu Riau. Pengalaman yang terus berulang memunculkan sebuah pemetaan dalam proses berbahasa sehingga penggunaan kata mata dapat menjadi sebagai penanda. Penanda ini menjadi penghubung maksud dari ungkapan yang disampaikan masyarakat Melayu Riau saat berkomunikasi.

\section{DAFTAR PUSTAKA}

Aidil, M., \& Istiqomalia, Y. (2021). Diksi dan Tradisi Syair Melayu dalam Lirik Lagu Nasyid Raihan. Al-I'lam; Jurnal Komunikasi dan Penyiaran Islam, 5(1), 70-84.

Akastangga, M. D. B. (2020). Metafora dalam Tarjuman Al-Ashwaq Karya Ibnu 'Arabi. Jurnal Listrendi: Jurnal Linguistik, Sastra, dan Pendidikan, 5(1), 27-46.

Ardhianti, M. (2019). Metafora dalam Teks Berita Hoaks di Media Sosial: Studi Semantik Kognitif. Jurnal Sastra Aksara, 7(2), 82-96.

Arianto, A. K. (2018). Medan Makna Pembentuk Metafora dalam Syair Arab Semantic Fields of Metaphore Perfomer in Arabic Poetry. Widyaparwa, 46(2), 112-125. https://doi.org/10.26499/wdprw.v46i2.197

Dessiliona, T., \& Tajudin, N. (2018). Metafora Konseptual dalam Lirik Lagu Band Revolverheld Album In Farbe. Sawerigading, 24(2), 177-184. https://doi.org/10.26499/sawer.v24i2.524 
Erfiani, Y. P. F., \& Neno, H. (2021). Analisis Makna Ungkapan Metafora dari Presenter Valentino "Jebret" Simanjuntak. Jurnal Onoma: Pendidikan, Bahasa, dan Sastra, 7(1), 249-259. https://doi.org/10.30605/onoma.v7i1.631

Firliandi, F. (2019). Keekspresifan Ungkapan Metafora dalam Media Daring Bidang Teknologi Informasi dan Telekomunikasi (Suatu Tinjauan Semantik). Nuansa Indonesia, 9(1), 148-162.

Hermandra, \& Zulhafizh. (2019). Manifestation of Malay Kinship Greetings in The Big Family of Kaharuddin and Zubaidah. Proceeding of the SS9 \& 3rd URICES 2019, 3(1), 693-700.

Jalaluddin, N. H., Sarudin, A., \& Ahmad, Z. (2012). Peluasan Makna Alim: Analisis Semantik Kognitif. GEMA Online Journal of Language Studies, 12(2), 457-473.

Kinanti, K. P., \& Rachman, A. K. (2019). Metafora Tumbuhan dalam Peribahasa Indonesia (Kajian Semantik Kognitif). Jurnal Belajar Bahasa, 4(1), 68-81. https://doi.org/10.32528/bb.v4i1.1867

Kusmanto, H. (2019). Konseptualisasi Metafora Wacana Politik: Studi Semantik Kognitif. WASKITA: Jurnal Pendidikan Nilai dan Pembangunan Karakter, 3(2), 27-41. https://doi.org/10.21776/ub.waskita.2019.003.02.3

Kustina, R. (2019). Makna Kiasan dalam Bahasa Jamee. Jurnal Metamorfosa, 7(2), 243-251.

Mangangue, J. (2019). Ungkapan Verbal dan Nonverbal Bermakna Budaya dalam Tari Tumatenden Masyarakat Tonsea Minahasa: Kajian Linguistik Antropologi. Jurnal Akrap Juara, 4(2), 21-30.

Mislikhah, S. (2014). Kesantunan Berbahasa. Ar-Raniry, International Journal of Islamic Studies, 1(2), 285. https://doi.org/10.20859/jar.v1i2.18

Soli, \& Sukirno. (2020). Aspek Stilistika dalam Antologi Cerpen Mastera dari Pemburu ke Terapeutik Pusat Bahasa Departemen Pendidikan Nasional dan Pembelajarannya di SMP. Jurnal Metafora, 7(1), 55-70. https://doi.org/10.30595/mtf.v7i1.9742

Sulistyaningsih, A. D., Samingin, F. X., \& Baihaqi, I. (2020). Pola Pikir Koplak dalam Novel Koplak karya Oka Rusmini dan Formulasinya sebagai Materi Ajar Apresiasi Sastra di SMA. Repetisi: Riset Pendidikan Bahasa Dan Sastra Indonesia, 3(2), 1-10.

Tama, S. Y., Ismail, S., Oroh, F. A., \& Kaluku, A. (2019). Analisis Kemampuan Berpikir Metafora pada Pokok Bahasan Barisan dan Deret. Euler: Jurnal Ilmiah Matematika, Sains dan Teknologi, 7(2), 45-50. https://doi.org/10.34312/euler.v7i2.10339

Tengku, F. H., \& Salehuddin, K. (2020). Reading Malay Literal and Metaphorical Expressions: An Eye Tracking Study. GEMA Online Journal of Language Studies, 20(2), 18-35. https://doi.org/10.17576/gema-20202002-02

Tumuju, V. N., \& Kamu, V. (2016). Ungkapan Metaforis Melayu Ternate di Desa Sea Tumpengan, Sea Mitra dan Buha. Jurnal LPPM Bidang EkoSosBudKum, 3(2), 29-42.

Warni, \& Afria, R. (2020). Analisis Ungkapan Tradisional Melayu Jambi: Kajian Hermeneutik. Sosial Budaya, $17(2), 83-94$.

Wiradharma, G. (2016). Metafora dalam Lirik Lagu Dangdut: Kajian Semantik Kognitif. Arkhais, 7(1), 5-14. https://doi.org/10.21009/ARKHAIS.071.02 